3. Bretthauer M. «Skall jag inte randomiseras?» Tidsskr Nor Legeforen 2010; 130: 1119.

4. Frich, L. Etablert, utprøvende eller eksperimentell? Tidsskr Nor Legeforen 2011: 131: 331

5. Bretthauer M, Haug C. Hva er etablert behandling? Tidsskr Nor Legeforen 2011; 131: 1275.

6. Evensen SA. Etikkvurdering ved innføring av ny behandling. Tidsskr Nor Legeforen 2011; 131: 1276.

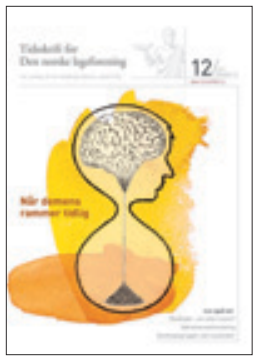

\section{Demens hos yngre og Huntingtons sykdom}

Rosnes og medarbeidere anslår i en oversiktsartikkel i Tidsskriftet nr. 12/2011 at det er om lag 1200 personer under 65 år med demens i Norge (1). Forfatterne gir en god beskrivelse av tilstander som Alzheimers sykdom, frontotemporal demens, vaskulær demens og lewylegemedemens. Demens ved Huntingtons sykdom karakteriseres som en «sjelden type» og sykdommen vies ikke nærmere omtale i artikkelen. Det er nødvendig å nyansere bildet artikkelen gir. Rosnes og medarbeidere oppgir som kilde McMurtray og medarbeidere (2) som fant fire tilfeller av Huntingtons sykdom hos totalt 278 pasienter med demens under 65 år. Studien bygger på et klinisk materiale av pasienter som var henvist til en hukommelsesklinikk, og det er helt åpenbart en seleksjonseffekt knyttet til henvisningen av pasienter. Personer med Huntingtons sykdom har ofte en familiehistorie og andre nevrologiske symptomer som gjør at de utredes og diagnostiseres ved nevrologiske avdelinger eller ved avdelinger for medisinsk genetikk. Harvey og medarbeidere fant $\mathrm{i}$ en befolkningsundersøkelse av forekomsten av demens hos personer under 65 år at én av 20 (ni av 185 tilfeller) hadde Huntingtons sykdom (3). På bakgrunn av hva vi vet om forekomsten av Huntingtons sykdom, gir også denne studien et for lavt estimat av andelen med Huntingtons sykdom i denne aldersgruppen. Forekomsten av Huntingtons sykdom er anslagsvis 7-10 per 100000 (4), og rapporter fra Storbritannia tyder på at forekomsten kan være enda høyere enn dette (5). Vi anslår at det er om lag 350-400 personer med Huntingtons sykdom i Norge. Gjennomsnittlig alder ved debut av sykdommen er 43 år, og de fleste utvikler symptomer i alderen 30-50 år. Kognitiv svikt, bl.a. i form av vansker med å gjøre flere oppgaver samtidig, redusert konsentrasjon, svekkede eksekutive funksjoner og svekket kortidsminne, er en del av sykdomsbildet, og slike vansker kan være uttalt alt $i$ tidlige stadier av sykdommen (4). Vi mener Rosnes og medarbeidere ikke gir et fullgodt bilde av hvilke diagnoser som er representert hos personer som er rammet av demens før fylte 65 år. Personer med Huntingtons sykdom er langt vanligere enn antydet og utgjør en betydelig andel av pasientene i denne aldersgruppen.

\section{Jan C. Frich}

Senter for sjeldne diagnoser Oslo universitetssykehus

\section{Arvid Heiberg}

Avdeling for medisinsk genetikk

Oslo universitetssykehus

Jan C. Frich (f. 1970) er dr.med., spesialist i nevrologi, rådgiver/overlege ved Senter for sjeldne diagnoser, Oslo universitetssykehus, og er førsteamanuensis ved Avdeling for helseledelse og helseøkonomi, Universitetet i Oslo. Ingen oppgitte interessekonflikter.

Arvid Heiberg (f. 1937) er dr.med., spesialist i indremedisin og i medisinsk genetikk og er tidligere avdelingsoverlege/overlege ved Avdeling for medisinsk genetikk ved Oslo universitetssykehus, Rikshospitalet. Han er tidligere professor i medisinsk genetikk ved Universitetet i Bergen.

Ingen oppgitte interessekonflikter.

\section{Litteratur}

1. Rosness TA, Haugen PK, Engedal K. Når demens rammer unge. Tidsskr Nor Legeforen 2011; 131: $1194-7$

2. McMurtray A, Clark DG, Christine D et al. Earlyonset dementia: frequency and causes compared to late-onset dementia. Dement Geriatr Cogn Disord 2006; 21: 59-64.

3. Harvey RJ, Skelton-Robinson M, Rossor MN The prevalence and causes of dementia in people under the age of 65 years. J Neruol Neurosurg Psychiatry 2003; 74: $1206-9$.

4. Novak MJU Tabrizi SJ. Huntington's disease. BMJ 2010; 340: c3109.

5. Ravlins M. Huntington's disease out of the closet? Lancet 2010; 376: 1372-3.

\section{T. Rosness \& K. Engedal svarer:}

Vi takker for kommentaren til Jan C. Frich \& Arvid Heiberg. Den overordnede målsettingen med vår oversiktsartikkel var å gjøre leger og helsepersonell oppmerksom på at demens kan forekomme i ung alder. Samtidig ønsket vi å understreke behovet for bedre utredning og behandling av unge pasienter med demens, og behovet for flere tilrettelagte dagsenter, korttids- og langtidsplasser på sykehjem. På grunn av begrenset spalteplass valgte vi å beskrive kun fire av de vanligste formene for demens som rammer i ung alder. Det betyr ikke at vi anser Huntingtons sykdom som en mindre viktig årsak. Vi la vekt på at genetiske faktorer forklarer en liten andel hos yngre med demens. Dette er ikke tilfelle med Huntingtons sykdom. Hver pasient med Huntingtons sykdom og deres pårørende har et godt definert tilbud i norsk helsevesen. De kan bli fulgt opp et av eget senter for sjeldne sykdommer (1). Dette står i kontrast til pasienter med andre former av demens som rammer tidlig, som frontotemporal demens, og deres pårørende. I Heibergs egen oversiktsartikkel om Huntingtons sykdom fra 2008 oppgis det å være 250 personer som til enhver tid har diagnosen i Norge i alle aldersgrupper; det blir ikke nevnt at dette er en årsak til demens hos yngre, og de kognitive endringene er ikke spesielt vektlagt (1). I en nyere studie med 811 inkluderte yngre demenspasienter fra hukommelsesklinikker, fant man 24 (3\%) tilfeller med Huntingtons sykdom (2), og det innebærer nok at flere av disse pasientene blir utredet ved andre instanser. I den oppgitte referansen fra Novak og medarbeidere oppgir forfatterne at dette er en relativt sjelden sykdom og nevner ikke at dette er en årsak til demens hos yngre. Tvert imot sier de i artikkelen at Huntingtons sykdom ikke forårsaker global demens, kun spesifikke kognitive utfall (3).

\section{Tor Rosness}

Villa Enerhaugen

Oslo kommune

Knut Engedal

Geriatrisk avdeling

Oslo universitetssykehus, Ullevål

Tor Rosness (f. 1976) er cand.med., ph.d., over lege på Villa Enerhaugen sykehjem i Oslo, som kun er for yngre med demens, og forsker på Kompetansesentret for aldring og helse. Ingen oppgitte interessekonflikter.

Knut Engedal (f. 1946) er professor i alderspsykiatri ved Universitetet i Oslo og er fagog forskningssjef ved Nasjonalt kompetansesenter for aldring og helse, Oslo universitetssykehus, Ullevål.

Ingen oppgitte interessekonflikter.

Litteratur

1. Heiberg A. Huntingtons sykdom. Tidsskr Nor Legeforen 2008: $128: 2214-7$.

2. Picard C, Pasquier F, Martinaud 0 et al. Early onset dementia: characteristics in a large cohort from academic memory clinics. Alzheimer Dis Assoc Disord 2010; e-publisert 28.12. 2010.

3. Novak MJ, Tabrizi SJ. Huntington's disease. BMJ 2010; 340: c3109 